
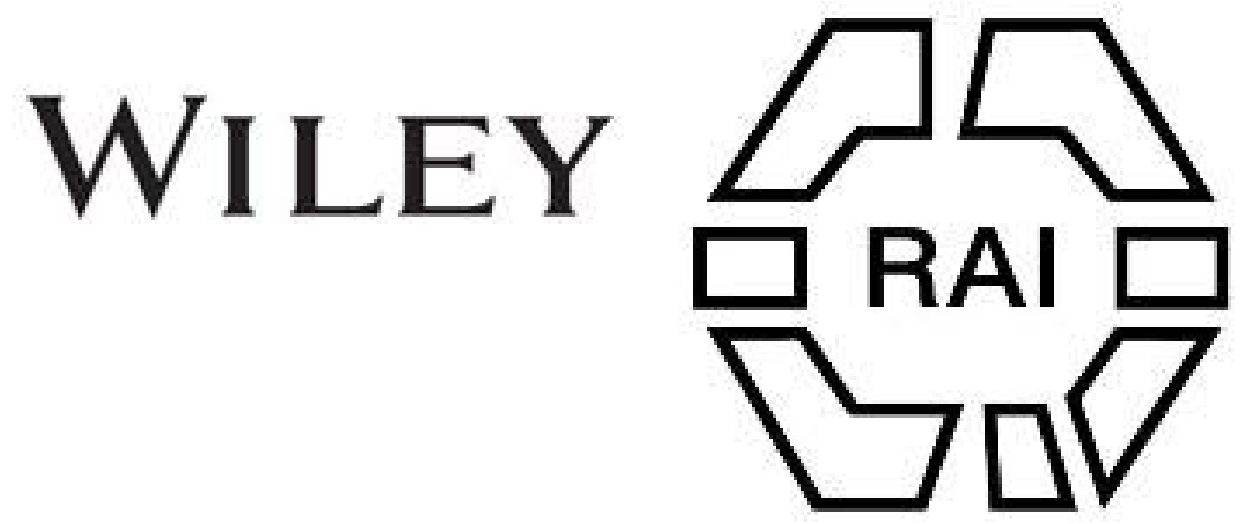

\title{
89. An American Dragon
}

\section{Author(s): G. Elliot Smith}

Source: Man, Vol. 18 (Nov., 1918), pp. 161-166

Published by: Royal Anthropological Institute of Great Britain and Ireland Stable URL: http://www.jstor.org/stable/2788324

Accessed: 27-06-2016 06:18 UTC

Your use of the JSTOR archive indicates your acceptance of the Terms \& Conditions of Use, available at

http://about.jstor.org/terms

JSTOR is a not-for-profit service that helps scholars, researchers, and students discover, use, and build upon a wide range of content in a trusted digital archive. We use information technology and tools to increase productivity and facilitate new forms of scholarship. For more information about JSTOR, please contact support@jstor.org.

Wiley, Royal Anthropological Institute of Great Britain and Ireland are collaborating with JSTOR to digitize, preserve and extend access to Man 


\section{ORIGINAL ARTICLES.}

\section{North America: Pottery. With Plate L. An American Dragon. By G. Elliot Smith.}

G. Elliot Smith.

Among the remarkable collection of Maya pottery in the Liverpool Free 84 Public Museums which Mr. Thomas Gann, M.R.C.S., obtained during the course of his excavations in the mounds of Northern Honduras, ${ }^{*}$ there is a peculiarly interesting object (Plate L) which Mr. Gann does not mention or represent in his series of illustrations. Yet Dr. Joseph A. Clubb, the curator of the Liverpool Museums, who called my attention to the specimen and kindly obtained for me the accompanying photograph of it, tells me that it was found at Santa Rita along with the specimens described by Mr. Gann, to which it presents obvious affinities.

It represents an alligator or crocodile, and a human face protrudes between the jaws of the open mouth. The head of the beast is equipped with such inappropriate appendages as deer's horns, which, though stunted, strictly conform to the stereotyped American way of representing antlers. $\dagger$ To the surface of the skin a series of elliptical (and in some cases circular) pieces of clay have been applied. Like all the other objects in the collection, the model was in the form of a hollow vessel with a large round opening upon the animal's back.

The maximum length of the specimen in its present condition (two spines have been broken off the tip of the tail) is $34 \cdot 6 \mathrm{~cm}$; the maximum breadth (across the arms) is $20.3 \mathrm{~cm}$., and the maximum height is $13.3 \mathrm{~cm}$., of which $3.9 \mathrm{~cm}$. consists of the cylindrical tube upon the crocodile's back, the diameter of which is $8.9 \mathrm{~cm}$. The fore limbs are provided with five toes and the hind limbs with four toes each. The antlers have three prongs. The human face is painted light blue, but the crocodile's palate is coloured brick red. Some of the elliptical elevations upon the creature show traces of blue paint. Bracelets and anklets are represented by series of hemispherical masses of clay.

The forms of several different animals are represented in the collection: tigers, turtles, sharks, as well as "alligators" (crocodiles), and human beings. Referring to "the alligator-like animal" (as well as its surrogates, the double-headed "alligator" and the turtle), Mr. Gann says: "it was intended to represent the Aztec "Cipactli, a mythic animal at times taking the form of a swordfish, a shark, an " alligator or an iguana"; but somewhat rashly, as the following discussion will show, adds the speculation that "it symbolizes the earth, and as in other cases, is " often represented with a human head between the jaws to signify that all flesh " returns to its original earth, and to death." (Footnote to p. 684.)

This suggestion is very wide of the mark, for the human head in the mouth belongs to the Rain God Chac (Tlaloc) and the animal-form, or his skin-covering, was nothing more than his traditional camoufage.

The crocodile in Japan, Indonesia, and India is perhaps the commonest form of the makara, which we can regard as a larval form of the real dragon, and in India the direct descendant of the Babylonian "goat-fish," the Capricornus of the Zodiac. One of the most interesting features of the American makara we are now studying is that it is equipped with such distinctive features of the Chinese and Japanese dragon as deer's antlers. The spottel decoration of the body is of exceptional interest. I have alresdy called attention to the fact that the elephantheaded god, the Maya Chac and the Aztec Tlaloc, was the American representative

* Thomas Gann: "Mounds in Northern Honduras," 19th Ann. Rep. Bureau of American Ethnology (1897-98), Part II. Washington, 1900, p. 661.

$\dagger$ E. Seler: "Die Tierbilder der mexikanischen und der Maya-Handschriften," Zeitsch. f. Ethnologie, Bd. 41, 1909, p. 414. G. G. MacCurdy: "A Study of Chiriquian Antiquities," Memoirs af the C'onnecticut Academy of Arts and Sciences, Vol. III, March 1911, p. 202, Fig. 342.

[ 161 ] 


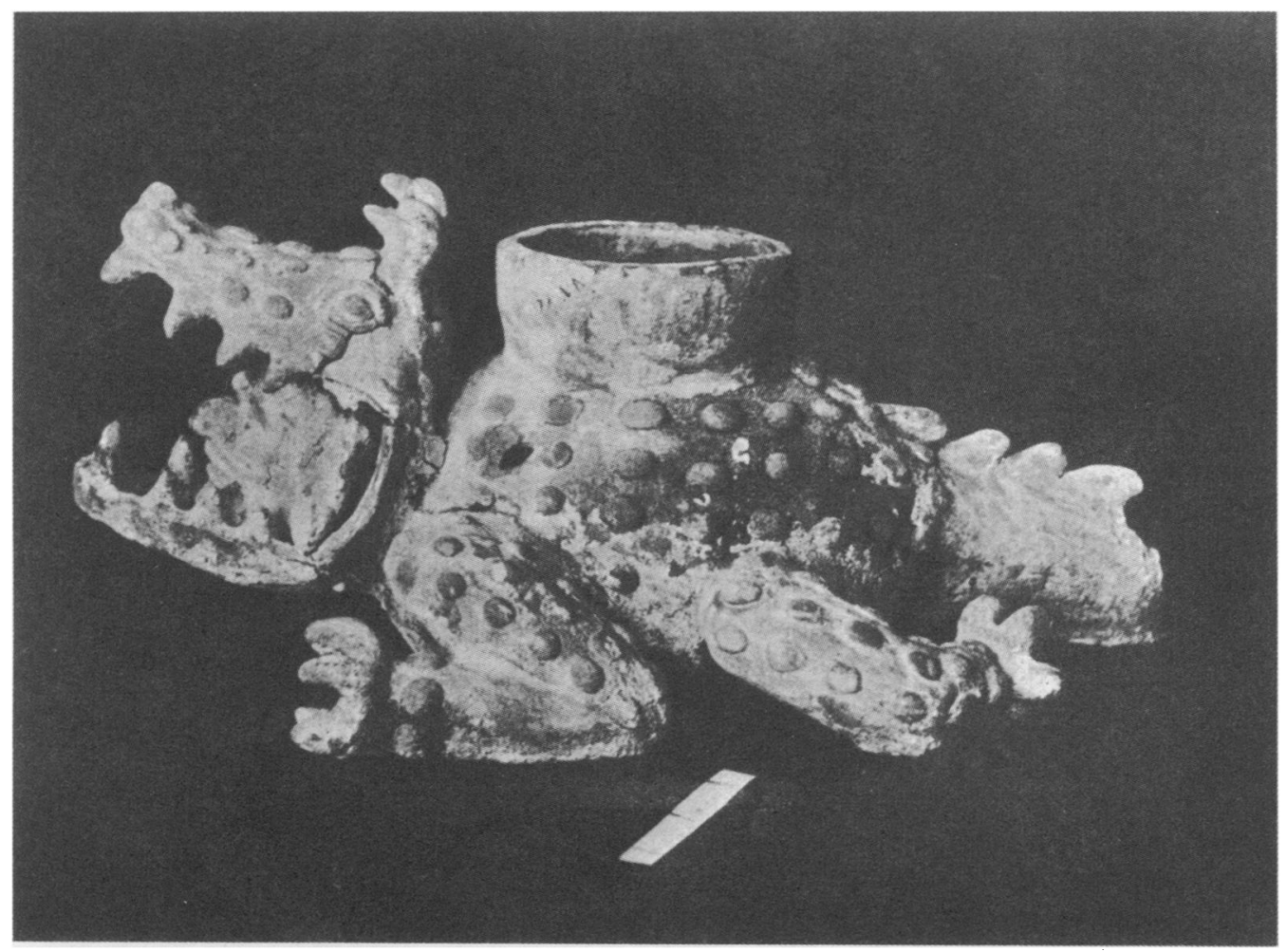

AN AMERICAN DRAGON.

This content downloaded from 131.247.112.3 on Mon, 27 Jun 2016 06:18:47 UTC All use subject to http://about.jstor.org/terms 
of the Vedic god Indra.* It was, in fact, a form of the Indian god somewhat modified by Cambodian and Indonesian, and especially locally by a variety of American influences.

In India, Indra had assumed many of the attributes of the gods Soma and Varuna, which were diversely specialised forms of the Babylonian Ea (Marduk) and the Egyptian Osiris (Horus): "In his aspect of Moon, 'the lord of stars,' [Soma] " has the antelope as his symbol. In fact, one of the names given to the Moon by " the early Indians was 'mriga-piplu,' or marked like an antelope," in reference to the spotted appearance of the moon. $\dagger$ "The Sanskrit name for the fifth Nakshatra " or lunar mansion over which Soma presides is 'mriga-siras,' or the 'deer" headed." " $\ddagger$

Dr. Gladys Davis has collected the evidence in substantiation of the claim that the Phrygian Dionysos was derived from the early Aryan god Soma (Haoma), who came into being somewhere in the neighbourhood of the Gates of Zagros. He was, in fact, Ea (Marduk), who passed through the Gates and became specialised as a highland deity. Miss Davis mentions an Orphic fragment preserved by Macrobius which refers to the star-aspect of Dionysos, and "explains the significance of the " $\nu \hat{\epsilon} \beta \bar{\rho} \iota s$ or fawn-skin worn by the god and his followers." The dappled appearance of the skin is supposed to symbolise the star-strewn sky, $\$$ and is further regarded by Orpheus as representing the connection of Dionysos with the sun. Here he tells how the god-

"First dons a robe like to its glittering rays

And bright as fire, then o'er his shoulder casts

The dappled fawn-skin garb of goodly width,

Dotted with countless eircles to portray

The stars inlaid in Heaven's hallowed vault."

-(Macrobius, Sat. I, 18.)

But not only Soma and Dionysos, but also their American representive Chac, wore "the dappled fawn-skin dotted with countless circles to portray the stars" in the pottery figure we are considering. But why should a crocodile be spangled with the antelope's " countless circles"?

It must be remembered that at the time when Ea (Marduk) was passing into the northern highlands to become the Aryan Soma (Haoma) or his spotted antelope, his other avatar, represented by a monster compounded of Ea's fish and untelope-the so-called "goat-fish" or Capricornus-was also being carried to India, where it became the makara. Not only did the makara assume protean forms, such as the "goat-fish," "tiger-fish," and elephant-fish" among many others, $\|$ but it

* Nature, January $27 \mathrm{th}, 1916$.

$\dagger$ It was primarily due to a confusion of the attributes of the moon and the sky, the spotted appearance being originally a graphic representation of the star-spangled sky when the first deities were devised by man and the Great Mother was identified in turn with a cow and the moon. But the human mind displays an instinctive tendency to integrate even the most diverse incidents in its experience; no gap is too great to be bridged by this process; hence primitive man solved the problem of the Great Mother's apparently incompatible homologies by making "the cow jump over the moon" and become the sky. Hence the Great Mother and her cowavatar were represented star-spangled, as the sow was in the Agean (Schliemann, Ilios, p. 616), and the deer (antelope or rabbit) in Asia and America.

† Gladys Davis: The Asiatic Dionysos, 1914, pp. 202 and 203.

$\S$ As the star-spangled skin of the Divine Cow Hathor (and perhaps also of the Mycenean Pig) represents the sky.

II See A. Cunningham: Report Arch. Survey of India, Vol. III, Plates IX and XXIX; and compare with William Hayes Ward, Cylinder Seals of Western Asia, p. 384, where the "goat fish" is shown as the vehicle of the Babylonian Ea, as the makara in India is the vehicle of Varuna. 
also became confused with the crocodile and the nâga. The identification of the crocodile with the antelope-fish* provides the reason for embellishing the American makara, with the spots of the antelope. In India the makara is the vebicle of Varuna, and the god was also identified with the monster, as Soma was with the antelope. In America both gods and their respective symbols are merged together in the spotted makara, as sometimes occurs also in India. $\dagger$

When the Babylonian cults made their influence felt, directly or indirectly, in Asia Minor and the Mediterranean area, the antelope of Ea was often replaced by the deer of Dionysos and Artemis. The horns of the dragon into which the "goat-fish" developed were transformed from those of an antelope into those of a deer by the time the dragon reached China and Japan.f It is possible, if not probable, that the idea of this composite monster (which certainly reached Eastern Asia from Babylonia) was transmitted to China by the overland route (vîa Turkestan, the Tian Shan line, past Lob Nor, to Shensi).

The influence of China and Japan in Indonesia in the early centuries of the Christian era was probably responsible for giving deer's horns to the makara (which Indonesia had aequired directly from India) while it was being conveyed east towards America. Hence the American dragon displays the results of a blending in Indonesia of the diversely specialised Indian and Chinese modifications of the original Babylonian antelope-fish of Ea (Marduk).

In a Japanese dragon-story, which was certainly inspired by certain Indonesian legends, $\S$ the dragon has a crocodile-form and is called a wani. In these myths the wani may be the hero's vehicle, as the makara was Varuna's, or the hero or heroine of the tale may be transformed into a wani. The literature relating to these mythical crocodiles is discussed by Dr. M. W. de Visser.\|

He quotes the following statement from Aston's Shinto: "There can be little " doubt that the wani is really the Chinese dragon. It is frequently so represented " in Japanese pictures. I have before me a print which shows Toyotama-hiko and " his daughter with dragons' heads appearing over their human ones. This shows " that he was conceived, not only as a Lord of Dragons, but as a dragon himself" (de Visser, p. 141). De Visser makes the following comment on Aston's statement : "We are here not so much on Chinese, as on Indian territory. . . . The " 'dragon's heads appearing over the human one' form quite an Indian motive, " transferred to China, and from there to Korea and Japan" (p. 142). The pottery figures from Honduras, as well as many statues from Central America, show that this conception spread, not only to Eastern Asia, but also across the Pacific to America. Among the many ways in which the nâga is represented in India, there is one in which the upper part of the god is shown as a human head with a snake's head above it. In Babylonia Ea was represented as a man wearing a fish's skin with the head above his own. The god and the animal whose skin he wore were identified the one with the other. In the Honduras figure, both the human figure and the crocodile represent the Rain God, Chac.

* In parts of Africa the dragon is an antelope (Frobenius, The Voice of Africa, 1913, Vol. II, p. 467, inter alia).

$\dagger$ Cunningham, op. cit., Plate XXIX.

$\ddagger$ It is not surprising to find the deer itself (as well as composite monsters) playing a considerable part in the mythology of America. Seler states : "Der Hirsch ist in hervorragendem "Masse eim mythologisches Tier. Er repräsentiert das Heer der Sterne, die, vom Morgensterne " gejagt, von Osten nach Westen getrieben werden."

$\S$ F. W. K. Müller : "Mythe der Kei-Insulaner und Verwandter," Zeitsch. f. Ethnologie, Bd. XXV (1893), p. 533.

|| "The Dragon in China and Japan," Verhandelingen der Koninklijke Akademie van Wetenschappen te Amsterdam, Afd. Letterkunde, Deel XIII, No. 2, 1913, pp. 139-142. 
That the makara-like whale-dragon of the Old World was transferred to America is also shown by the remarkable Maya story, translated by Juan Martinez Hernández," in which the reference to a "female whale with alligator's feet" recalls the pictures on the Buddhist railing at Mathura (circa 70 B.c. -70 A.D.); whereas the exploits associated with this monster are equally definitely a travesty of Indra's famous achievement in overcoming the demon Vritra.

The world-wide stories of the whale-dragon have been collated by Frobenius. $\dagger$

Iu his Study of Chiriquian Antiquities $\ddagger$ MacCurdy gives an interesting account of a class of Chiriquian pottery which Holmes called "the alligator group," although, for the reasons clearly set forth by MacCurdy, the animal depicted was probably Crocodilus Americanus, var-acutus, and not the alligator (Alligator punctulatus). which has a shorter muzzle. In the ancient Mexican picture-writing also it was the crocodile that was figured as cipactli (op. cit., p. 126).

MacCurdy is puzzled to explain "the appearance of a long crest that is attached "to the back of the neck, the meaning of which is not clear" (p. 127). Comparison with the Honduras pottery suggests that this appendage is merely the vestigial remains of the deer's horns of the dragon, conventionalised in the characteristically Babylonian fashion as a single crook-like spur proceeding backwards above the neck (compare his figures 208 and 209, p. 127, with the dragon on the Ishtar Gate at Babylon-L. W. King's History of Babylonia and Assyria).

In some of the Honduras specimens the crocodile is given a second head, which is fixed to the end of its tail, in strict conformity with the principles of dragon-construction in the Old World. $\$$

I do not think that MacCurdy's account of the mechanism of conventionalisation of the Chiriquian crocodile gives adequate recognition to the complexity of the process.

The essential factor in the conventionalisation has been the blending of several different conceptions. The design of the crocodile itself is already embellished with vestigial structures that reveal its origin in the Old World. To this is added the effects of the blending in Chiriqui with locally developed designs, as well as with those which have been introduced from abroad, not only in association with the makara, but also independently of it. I think the sagging of the body of the Chiriquian crocodile may have been the result of the use of animal forms for metate-designs described elsewhere in MacCurdy's report.

Every stage in the process of blending of the crocodile and the pot is seen in the Chiriquian series, and the completed stage is revealed in the Honduras specimen with which this note is especially concerned.

It is important to remember that the conception of the Great Mother as a water-pot, which was widely accepted in the Old World (in Egypt, 9 the Mediterranean area,** Western Europe, $† \dagger$ India, $¥ \ddagger$ Indonesia, Eastern Asia, and Oceania§\$),

* "La Creación del Mundo Segun los Mayas," Páginas Inéditas del MS. De Chumayel, International Congress of Americanists, Proceedings of the XVIII Session, London, 1912, p. 164.

$\dagger$ Das Zeitalter des Sonnengottes, Berlin, 1904.

$\ddagger$ George Grant MacCurdy : Memoirs of the Connecticut Academy of Arts and Sciences, Vol. III, March, 1911, p. 125, et seq.

$\S$ See Budge's Gods of the Egyptians, Vol. I.

II See Plate III.

ๆ F. Ll. Griffith : "A Collection of Hieroglyphics," Arch. Survey of Egypt, 1898, p. 3 ; also §§.

** Schliemann, op. cit.; also §§.

†† The Holy Grail story ; also §§.

If Bishop Whitehead: "The Village Deities of Southern India," Madras Government Museum Bulletin, Vol. V, No. 3, 1907, where the seven goddesses are represented by seven pots.

\$ In my Etolution of the Dragon I have discussed the origin of the Mother Pot. 
was blended in the Egean area with another of her forms, the octopus; and in the so-called "owl-shaped vases" found in such profusion by Schliemann, we find the "Mother Pot" represented as a jar in the form of a highly conventionalised octopus which is also a woman, whose pudendum is sometimes embellished with a swastika or a volute, two other symbols which Houssay claims as conventionalisations of the octopus.* Similar elements of culture were being mingled in Chiriqui; and it is interesting to compare the compound formed by the American designers of essentially the same ingredients as their Minoan and Mycenæan forerunners used to make their cultural mixture several centuries earlier. For the Chiriquians not only received the suggestions of making such objects from the Old World, but also learned the principles of mingling the motives which inspired them.

I have already referred to the widespread conception of the earliest goddess as a bowl. In conformity with the confusion between the moon-goddess of Egypt and the moon-gods of Aryan India and Persia, it is not surprising to find the god Soma represented as a golden bowl. $\dagger$ The moon itself was regarded in India as a bowl with a spotted antelope or rabbit in it, $\ddagger$ or as an animal-shaped vessel.

This Indian conception of the moon also spread to China. Ancient Chinese embroideries represent the moon as a hare pounding medicinal herbs in a mortar under a cassia tree. $\S$ In this form the hare is probably the representative of the Egyptian Hathor, whose priestesses pounded the materials for the elixir of life.

This idea also was carried across the Pacific in Pre-Columbian times. In ancient Mexican codices the moon is represented as a bowl in which a hare or rabbit, spotted in the characteristic Indian way, is pounding the Agave plant to make the sacred drink, pulque.

In Mexico the Pulque God was in many respects like the Indian Soma, or the Greek Dionysos; and there is no doubt that the American god was derived from the Vedic drink-god. The Pulque God was not only the moon, but was also known as the "Four Hundred Rabbits."

Kunike reproduces a remarkable "Mexican Saga" (Sahagun VII, 2), which explains the present diminution of the moon's brightness by the statement that the

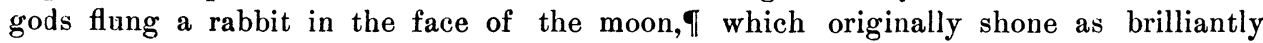

* Frédéric Houssay : "Les Theories de la Genèse à Mycènes et lessens zoologique de certains " symboles du culte d'Aphrodite," Revue Archéologique, 3rd Series, XXVI, 1895, p. 24.

$\dagger$ Davis, op. cit., p. 239.

I In another Indian legend a celestial being, an emanation of Brahma, brings down from heaven in a golden vessel the food of the gods-pyassa, compounded of rice and milk, both of them "givers of life." Wives who eat this fertilising mixture give birth to sons who are incarnations of -Vishnu, and overcome the king of the demons.

$\S$ De Gubernatis, Myth. des Plantes, Tome II, p. 50; John Steele, The I-Li, London, 1917, represents (Vol. I, plate facing p. 144) a deer-shaped tally-holder from China, with striking analogies to the Honduras pot.

|| Seler: Codex Vaticanus, Vol. I., p. 167. In his account of this god, Seler quotes from an ancient document deseribing how four male demons killed the Great Mother, the mother of all the gods and demons, and thereby fouuded the institution of human sacrifice. They took her heart out and presented it to the sun . . . in this way giving him eternal life, and that, if he did not die, all persons drinking wine must die; but the death of this Ometochtli was like the sleep of one drunk, and afterwards he recovered and became fresh and well. This is a curious blend of the Egyptian story of the Destruction of Mankind and the Babylonian legend of Tiamat.

I Elsewhere I have referred to the remarkable practice of the Pyramid Age in Egypt of offering the fore-limb torn from a living calf as a blood offering, and of the survival of this custom in a modified form among the Dravidian people of India at the present day. In Babylonia Eabani is said to have torn a limb from the Celestial Urus and to have thrown it in the face of Ishtar (Maspero, Dawn of Civilisation, p. 582). Is the story of the flinging of the rabbit in the face of the moon (the Great Mother) a garbled version of this ancient legend? 
as the sun. He states that the "Sanskrit Indians" have the same legend, and that the Japanese and the Indians of Central Brazil refer to the rabbit in the moon.*

I have already referred to the confusion of sex that occurred when many attributes of the Egyptian female moon-god were acquired by the Indian drink-god Soma. A remarkable illustration of this confusion is provided by the Mexican god Xipe, who carries the characteristic sistrum of Hathor. $\dagger$ Kunike says : "Das Kaninchen “ ist also der Mond und die Pulquegötter sind Mondgötter, auch sie "hängen wie “ Xipe (als Mond-und Vegetationsgott) mit den Ideen der Lebensmittelfülle unmittel" bar zusammen" (p. 927).

As in Egypt, so also in Mexico, the moon is represented as an eye. When represented as a bowl the latter may simply be a part of the conventional eye-design (see Kunike, Fig. 9, p. 926); or it may be a real bowl containing a rabbit, a seashell or a flint knife, three of the diverse forms which the Great Mother assumes in the Old World, the rabbit (or its surrogates, the antelope, the gazelle, or the deer) being her good or evil avatar, the shell her original form, and the flint-knife also an animate form of the goddess as well as the original thunder-weapon. Thus we find upon the shores of the New World a confused jumble of beliefs and fancies that began to drift across the Pacific from the Old World more than twenty centuries ago. As we examine the pictures in the ancient Maya and Aztec codices, a neverending feeling of amazement is awakened as one after another almost every incident in the mythology of India, Babylonia, and Egypt, the legends of their gods and demons, the history of their dragons and thunder-weapons, make their appearance, flung together in kaleidoscopic confusion, and elaborated with childish directness and barbaric luxuriance of embellishment, into new combinations and distinctively American designs.

No one who conscientiously studies the mythology of the Old World and appreciates the fortuitous circumstances which determined the arbitrary forms assumed by many of the beliefs and ideas can refuse to admit that the confused mosaic of the identical elements of culture in America must have come from the other side of the Pacific, and for the most part received the impress of Indian civilisation before the fragments were rearranged and built up again into a new pattern in Mexico and Central America.

In my book of Rylands lectures on "The Evolution of the Dragon," I have discussed at greater length the general problems mentioned here. It was only after the relevant chapter of the book was in printed proof that $I$ learned of the existence of this pottery figure in Liverpool, which affords a most remarkable demonstration of the existence of such a mythical creature as the development of my argument had previously led me to expect to find in America. G. ELLIOT SMITH.

\section{Africa, East.}

Crossland.

Notes on the East African Outrigger Canoe. By Cyril Crossland.

The following notes are taken from a letter from Cyril Crossland to Professor Seligman (June, 1918) by way of comment on my paper on "The Outrigger Canoe of East Africa" (MaN, 1918, 29).-A. C. Haddon.

"I am inclined to think that Mr. Montgomery's observation that the 'hori' is only used in calm weather, and inside the reef, is due to its not being adapted for long, swift journeys, as the galawa is. J believe our huris come from India vîa Arabia. Zanzibar ones may also, but I remember watching one being made [in Zanzibar ?] from the trunk of a mango tree. Our huris get patched and repatched

* Hugo Kunike: " Finige grundsätzliche Bemerkungen über Sonne, Mond and Sterne in alten Mexiko," Zeitschrift fur Ethnologie, Bd. 43, 1911, p. 926.

† Joyce : Mexican Archaology, p. 40. 